\title{
SENSITIVITAS MATA AIR KARST GOA GREMENG TERHADAP HUJAN DI AREA TANGKAPANNYA
}

\author{
Eko Budiyanto dan Eka Puji Lestari \\ Jurusan Pendidikan Geografi, FISH, Unesa \\ Jl. Ketintang No 1, Ketintang, Surabaya
}

\begin{abstract}
Abstrak : mata air merupakan satu bentuk sumberdaya air yang vital bagi masyarakat di wilayah karst. Bentang lahan karst yang rentan memerlukan pengelolaan lingkungan yang tepat untuk melindungi kelestarian mata air tersebut. Mata air karst Goa Gremeng adalah satu contoh mata air di lingkungan karst Gunungsewu yang perlu dikelola dan dilindungi. Air dari mata air ini dimanfaatkan oleh penduduk untuk beberapa keperluannya. Dalam rangka upaya perlindungan mata air karst Goa Gremeng, maka perlu dipahami karakteristik dari mata air ini terutama berkaitan dengan sensitivitasnya terhadap hujan. Tujuan dari penelitian ini adalah untuk mengetahui sensitivitas mata air Goa Gremeng terhadap hujan di area tangkapannya. Metode yang dilakukan adalah dengan pengukuran dan observasi terhadap fluktuasi parameter kualitas air dan dikorelasikan dengan pola curah hujan yang turun di area tangkapannya. Parameter yang diukur adalah $\mathrm{pH}$, TDS, kekeruhan, temperature, DO, dan nitrat. Pengukuran dilakukan secara langsung di lapangan dan di laboratorium. Penelitian ini menunjukkan adalah fluktuasi beberapa parameter kualitas air yang memiliki korelasi sangat kuat dan kuat terhadap tebal hujan. Parameter TDS memiliki korelasi negative sangat kuat yaitu sebesar -0,85. Parameter kekeruhan memiliki korelasi positif yang kuat yaitu sebesar 0,76 . Parameter nitrat dan temperature memiliki korelasi negative yang kuat yaitu masing-masing sebesar $-0,73$ dan $-0,65$. Korelasi tertinggi dari parameter-parameter tersebut terhadap tebal hujan terjadi pada hari yang sama dengan saat pengukuran parameter kualitas air. Temuan ini mengindikasikan bahwa mata air karst Goa Gremeng memiliki tingkat sensitivitas yang tinggi terhadap hujan di area tangkapannya.
\end{abstract}

Kata kunci : Sensitivitas, mata air karst, Goa Gremeng

\section{A. PENDAhULUAN}

Air merupakan sumberdaya yang vital bagi masyakarat di wilayah karst seperti karst Gunungsewu (Ford dan William, 2008; Widyastuti, 2014). Besarnya porositas sekunder pada lahan karst mengakibatkan langkanya air di permukaan. Air sebagian besar terinfiltrasi melalui celah, rekah, dan kekar pada batuan. Air selanjutnya berkumpul pada lorong-lorong di bawah permukaan karst sebagai sungai-sungai bawah tanah. Proses ini sering memicu kelangkaan air dan kekeringan di permukaan lahan karst.

Banyaknya celah dan rekah pada batuan dalam berbagai ukuran memungkinkan bahan pencemar mudah masuk ke dalam sungai bawah tanah karst. Bahan pencemar ke dalam celah tersebut bersama dengan air dari permukaan. Tanah dan vegetasi yang ada 
pada lahan karst sering tidak efektif menahan masuknya bahan pencemar ke dalam lubang di permukaan karst. Oleh karena itu, area yang tidak dikelola dengan baik, potensi pencemaran air bawah tanah karst menjadi lebih besar.

Pengelolaan lingkungan karst memerlukan pemahaman yang baik terhadap karakteristik lingkungan karst tersebut. Kesalahan dalam pengelolaan lingkungan karst justru dapat mengakibatkan kerusakan lingkungan yang lebih buruk. Salah satu karakteristik penting yang perlu dipahami adalah sensitifitas mata air tersebut terhadap kejadian hujan yang terjadi di area tangkapannya. Kerentanan mata air untuk tercemar sejalan dengan tingkat sensitifitasnya terhadap kejadian hujan.
Sejalan dengan hal tersebut di atas, guna pengelolaan lingkungan area tangkapan mata air karst Goa Gremeng, diperlukan penelitian yang mampu mengidentifikasi karakteristik mata air ini. Penelitian ini adalah bentuk dari upaya perlindungan dan pengelolaan mata air karst Goa Gremeng. Tujuan dari penelitian ini adalah untuk mengetahui tingkat sensitifitas mata air Goa Gremeng terhadap kejadian hujan yang terjadi di area tangkapannya.

\section{B. METODE PENELITIAN}

Penelitian ini dilaksanakan di mata air karst Goa Gremeng yang terletak di Desa Sumbergiri, Kecamatan Ponjong. Gambar 1. berikut menunjukkan lokasi area tangkapan mata air karst Goa Gremeng.

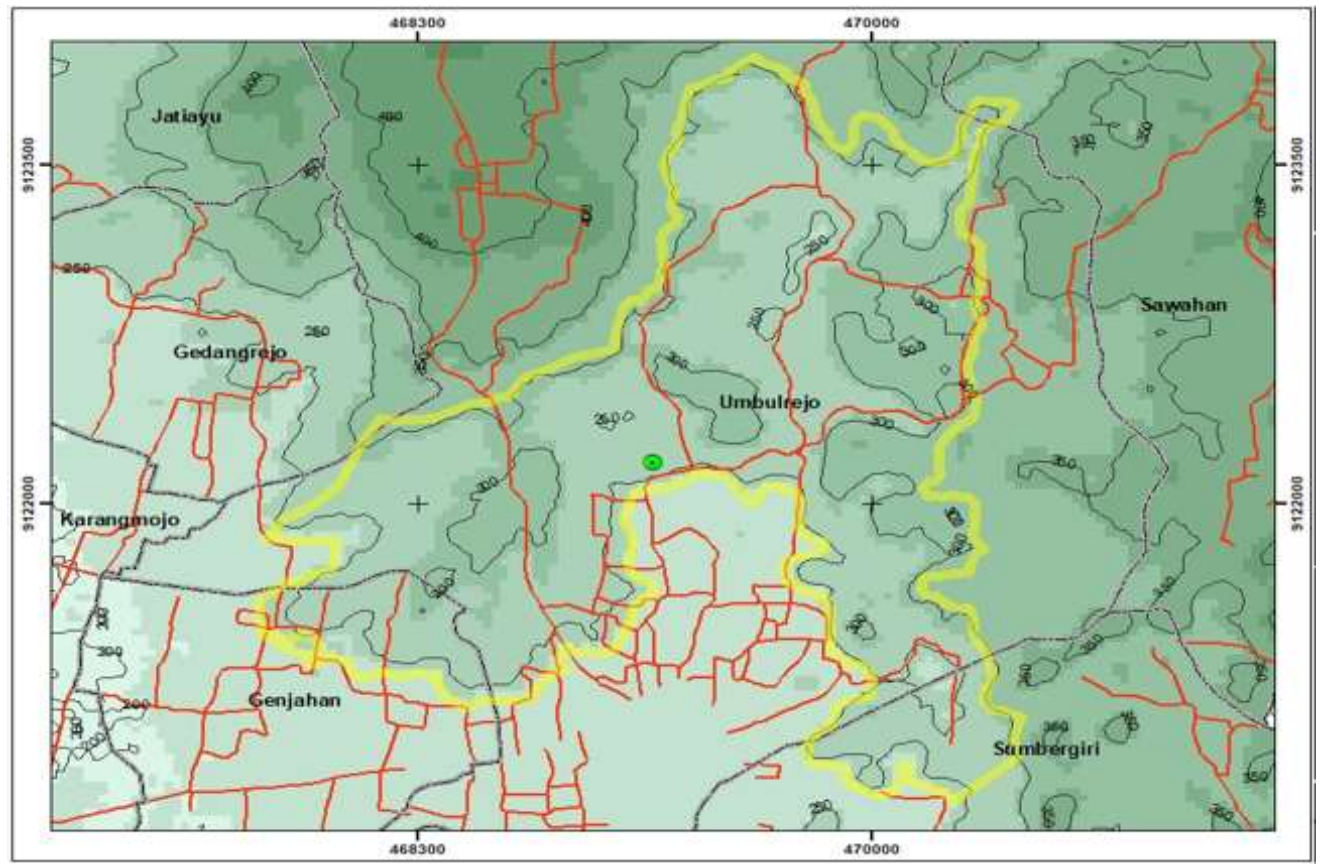

Gambar 1. Area tangkapan mata air karst Goa Gremeng (sumber : pengolahan dan interpretasi citra, 2019) 
Mata air ini beserta area tangkapannya masih termasuk pada area karst Gunungsewu. Sensitifitas mata air dalam penelitian ini diukur berdasar konsep waktu lintas air bawah tanah menuju mata air seperti dicontohkan oleh Ravbar (2007). Waktu lintas air dari permukaan menuju mata air diidentifikasi dengan adanya perubahan konsentrasi parameter kualitas air tanah yang selaras dengan pola intensitas curah hujan di area tangkapan mata air. Pengukuran dilakukan pada tanggal 21 hingga 30 Januari 2019. Pada tanggal tersebut wilayah penelitian telah masuk pada musim penghujan.

Sampel air bawah tanah diambil pada mulut goa selama tujuh hari secara berurutan. Satu hari amatan diwakili oleh satu sampel air. Parameter kualitas air yang diukur adalah pH, TDS, DO, Temperatur, Nitrat, dan kekeruhan. Parameter pH, TDS, DO, dan temperature diukur secara langsung di lapangan dengan menggunakan peralatan pengukuran lapangan. Peralatan pengukuran lapangan ini adalah Ohaus ST20 untuk pengukuran $\mathrm{pH}$ dan temperature, DO meter Lutron DO-5509 untuk pengukuran DO, dan TDS Meter Hanna 1 untuk pengukuran TDS. Parameter nitrat dan kekeruhan diukur di laboratorium BBTKL Depkes Propinsi
DIY. Data curah hujan diambil dari Dinas Pertanian Kecamatan Ponjong yang memiliki stasiun hujan terdekat dari lokasi penelitian. Data curah hujan yang diambil adalah data tebal hujan yang terjadi pada tujuh hari sebelum pengambilan sampel hingga hari terakhir pengambilan sampel.

Seluruh nilai parameter kualitas air dituangkan dalam tabel sehingga terbentuk daftar nilai kualitas air harian. Kolom pada tabel menunjukkan nilai kualitas air, sedangkan baris menunjukkan tanggal atau hari pengambilan sampel. Selanjutnya masing rangkaian data kualitas air tersebut dikorelasikan dengan rangkaian data curah hujan menggunakan model korelasi sederhana. Perhitungan korelasi dilakukan sebanyak tujuh kali. Pengulangan ini untuk mengetahui tingkat keeratan pola fluktuasi curah hujan dengan pola fluktuasi parameter kualitas air pada hari yang sama saat pengambilan sampel hingga tujuh hari sebelum hari pengambilan sampel tersebut. Pola curah hujan yang memiliki korelasi tinggi dengan pola fluktuasi nilai parameter kualitas air mengindikasikan adanya keterkaitan antara hujan yang terjadi di area tangkapannya dengan fluktuasi kualitas air. 
Nilai-nilai korelasi hasil perhitungan ditabulasi secara berurutan untuk masing-masing parameter kualitas air. Tabel ini akan menunjukkan sebaran nilai korelasi pola curah hujan dengan fluktuasi parameter kualitas air mata air Goa Gremeng. Nilai kolom dari paling kiri adalah nilai korelasi dari hari saat pengambilan sampel. Kolom selanjutnya adalah nilai korelasi hingga tujuh hari sebelum pengambilan sampel. Penilaian sensitivitas didasarkan pada sebaran nilai korelasi pada tabel ini. Sensitivitas mata air yang tinggi ditunjukkan oleh adanya nilai korelasi tinggi pada saat bersamaan atau dekat dengan waktu pengambilan dan pengukuran kualitas air. Jika terdapat nilai korelasi tinggi pada saat pengambilan dan pengukuran sampel maka dinyatakan bahwa mata air karst Goa Gremeng memiliki nilai sensitivitas yang tinggi. Sebaliknya jika korelasi yang ada bernilai lemah atau jauh dengan saat pengambilan dan pengukuran sampel maka dinyatakan mata air karst Goa Gremeng tidak memiliki tingkat sensitivitas yang tinggi.

\section{HASIL DAN PEMBAHASAN \\ C.1. Hasil Penelitian}

Kejadian hujan di wilayah penelitian diketahui dari data curah hujan yang diambil dari Stasiun Hujan milik BPP Pertanian Ponjong - Dinas Pertanian Kabupaten Gunungkidul. Curah hujan yang terjadi selama pengambilan dan pengukuran kualitas air adalah seperti pada Gambar 2.

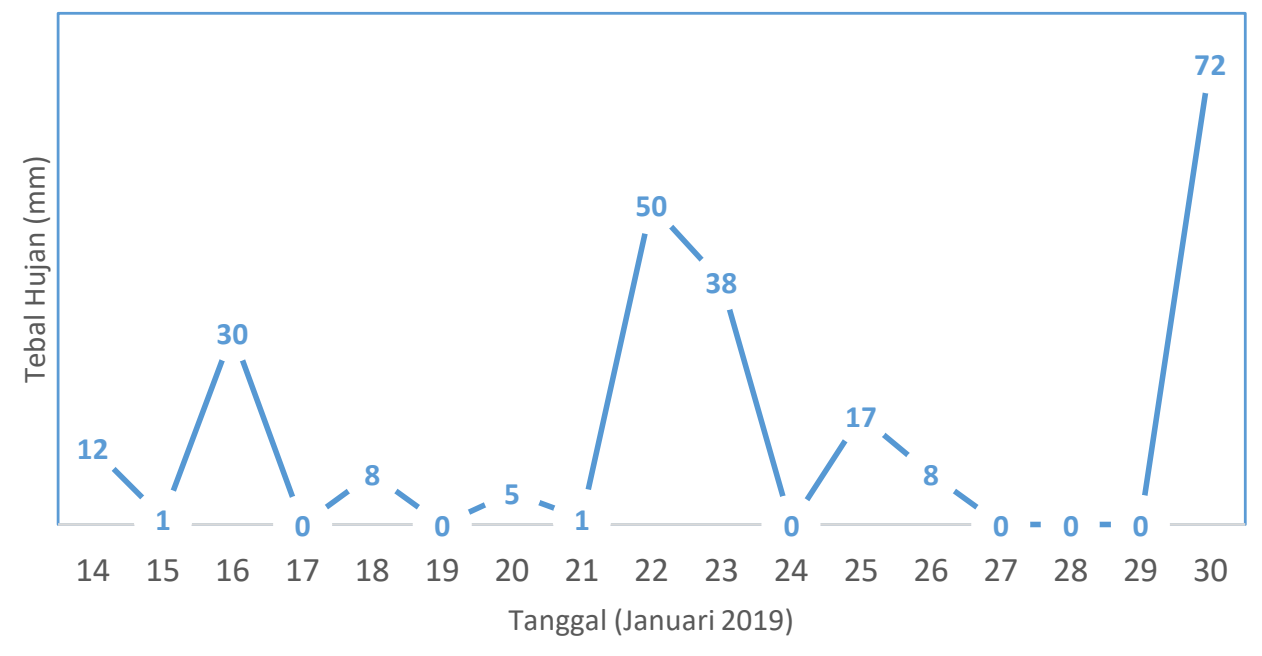

Gambar 2. Curah hujan selama pengukuran sampel (sumber : pengolahan data, 2019)

Terdapat fluktuasi curah hujan selama masa pengukuran dan pengambilan sampel. Selama masa tersebut, terdapat beberapa hari tidak 
hujan seperti pada tanggal 17, 19, 24, dan 27 hingga 29 Januari 2019. Hujan dengan volume tebal dibawah $10 \mathrm{~mm}$ terjadi pada tanggal 18, 20, dan 26 Januari 2019. Hujan yang terjadi pada hari-hari tersebut berupa hujan ringan dengan durasi tidak menentu. Hujan dengan volume besar terjadi pada tanggal 16, 22, 23, dan 30 Januari 2019. Hujan dengan durasi yang panjang terjadi antara tanggal 20 hingga 23 Januari 2019.

Respon mata air Goa Gremeng terhadap hujan di area tangkapannya diidentifikasi melalui perubahan kualitas airnya. Kualitas air yang diukur pada mulut Goa Gremeng menghasilkan data seperti pada Tabel 1. berikut.

Tabel 1. Hasil pengukuran kualitas air di mulut Goa Gremeng

\begin{tabular}{ccccccc}
\hline Tanggal & $\begin{array}{c}\text { Turbid } \\
(\mathrm{NTU})\end{array}$ & $\begin{array}{c}\mathrm{TDS} \\
(\mathrm{Mg} / \mathrm{L})\end{array}$ & $\begin{array}{c}\text { Temp } \\
\left({ }^{\circ} \mathrm{C}\right)\end{array}$ & $\begin{array}{c}\mathrm{DO} \\
(\mathrm{mg} / \mathrm{L})\end{array}$ & $\mathrm{pH}$ & $\begin{array}{c}\text { Nitrat } \\
(\mathrm{mg} / \mathrm{L})\end{array}$ \\
\hline $\mathbf{2 1}$ & 5.4 & 127 & 27 & 0.7 & 8.5 & 1.24 \\
\hline $\mathbf{2 2}$ & 142 & 55 & 24.7 & 0.6 & 9.1 & 0.8 \\
\hline $\mathbf{2 3}$ & 81 & 73 & 26.3 & 0.7 & 8.3 & 0.89 \\
\hline $\mathbf{2 4}$ & 39.5 & 106 & 27.8 & 0.6 & 8.3 & 1.7 \\
\hline $\mathbf{2 5}$ & 17.6 & 117 & 26.5 & 0.7 & 8.5 & 1.33 \\
\hline $\mathbf{2 6}$ & 13.9 & 97 & 26.6 & 0.6 & 8.4 & 1.16 \\
\hline $\mathbf{2 7}$ & 16.2 & 119 & 28 & 0.4 & 8.4 & 0.87 \\
\hline $\mathbf{2 8}$ & 8.5 & 96 & 27.7 & 0.4 & 8.5 & 1.13 \\
\hline $\mathbf{2 9}$ & 5.8 & 114 & 27.5 & 0.4 & 8.5 & 1.06 \\
\hline $\mathbf{3 0}$ & 2740 & 67 & 26.8 & 0.2 & 8.5 & 0.48 \\
\hline
\end{tabular}

Sumber : Data Primer, 2019

Tabel 1 tersebut menunjukkan fluktuasi nilai parameter kualitas air harian. Seluruh parameter menunjukkan perubahan kondisi kualitasnya selama masa pengambilan sampel. Kondisi relative stabil ditunjukkan oleh parameter DO dan $\mathrm{pH}$ yang tidak banyak menunjukkan perubahan secara nyata. Sementara itu kekeruhan menunjukkan adanya perubahan kondisi terutama ditunjukkan oleh sampel tanggal 30 Januari 2019.

Keterkaitan pola fluktuasi curah hujan dengan nilai parameter kualitas air diketahui melalui pengujian korelasi. Hasil uji korelasi antara rangkaian data hujan dengan nilai parameter kualitas air menunjukkan hasil sebagai berikut. 
Tabel 2. Nilai korelasi curah hujan dengan parameter kualitas air

\begin{tabular}{|c|c|c|c|c|c|c|c|c|}
\hline \multirow[t]{2}{*}{ Parameter } & \multicolumn{8}{|c|}{ Tebal Hujan Hari ke } \\
\hline & $\mathbf{0}$ & -1 & -2 & -3 & -4 & -5 & -6 & -7 \\
\hline TDS & -0.85 & -0.15 & 0.34 & 0.32 & 0.16 & 0.33 & -0.13 & -0.11 \\
\hline Turbid & 0.76 & -0.22 & -0.24 & -0.27 & -0.11 & 0.02 & -0.25 & 0.45 \\
\hline nitrat & -0.73 & 0.30 & 0.69 & 0.36 & -0.12 & -0.22 & 0.01 & -0.46 \\
\hline Temp & -0.65 & 0.05 & 0.28 & -0.08 & 0.16 & 0.51 & 0.03 & 0.07 \\
\hline $\mathrm{pH}$ & 0.41 & -0.53 & -0.24 & -0.14 & -0.14 & -0.18 & 0.41 & -0.16 \\
\hline $\mathrm{DO}$ & -0.26 & 0.44 & 0.26 & 0.38 & -0.19 & -0.35 & -0.29 & -0.40 \\
\hline
\end{tabular}

Perhitungan korelasi data curah hujan dan nilai parameter kualitas air seperti ditunjukkan pada Tabel 2 di atas. Berdasar Tabel 2 tersebut tampak adanya perbedaan nilai korelasi antara tebal hujan dengan nilai masing-masing parameter. Perbedaan nilai korelasi juga terjadi pada hari pengukuran sampel. Hujan yang terjadi pada hari yang sama dengan saat pengukuran sampel memiliki korelasi paling tinggi dibandingkan dengan hujan yang terjadi pada hari sebelum pengukuran sampel. Berdasar parameter kualitas air yang diukur, TDS memiliki korelasi yang paling tinggi dibandingkan parameter kualitas air yang lain.

\section{C.2. Pembahasan}

Tebal hujan yang terjadi di wilayah penelitian bervariasi selama masa pengukuran dan pengambilan sampel. Terdapat beberapa hari yang memiliki curah hujan tinggi sehingga dimungkinkan adanya penambahan pasokan air pada area tangkapan mata air
Gremeng. Kondisi ini selaras dengan data Budiyanto (2018) dimana bulan Januari merupakan masa musim penghujan di wilayah karst Gunungsewu.

Nilai kualitas air mata air Gremeng memiliki fluktuasi yang berbeda antar satu parameter dengan parameter yang lain. Parameter $\mathrm{pH}$ dan DO memiliki fluktuasi yang paling kecil. Nilai pH mata air Goa Gremeng berkisar antara 8,3 hingga 9,1. Hal ini memiliki kemiripan dengan temuan Budiyanto (2018) pada beberapa mata air di wilayah karst Gunungsewu dan Adji (2010) pada beberapa sampel sungai bawah tanah amatannya. Kondisi ini mengindikasikan bahwa area tangkapan mata air Goa Gremeng merupakan wilayah karst yang merupakan bagian dari karst Gunungsewu. Fluktuasi yang besar ditunjukkan oleh nilai parameter kekeruhan. Tingkat kekeruhan paling tinggi terjadi pada tanggal 30 Januari 2019 yang mencapai nilai 2740 NTU. 
Nilai korelasi dari data hujan dan data parameter kualitas air mengindikasikan adanya keterkaitan antara hujan dengan kondisi kualitas air mata air Gremeng. Perubahan kondisi kualitas air seperti ditunjukkan oleh fluktuasi nilai parameter kualitas air tersebut selaras dengan pola curah hujan yang terjadi di area tangkapannya.

Terdapat parameter yang menunjukkan korelasi positif seperti dicontohkan oleh parameter kekeruhan dengan nilai korelasi yang kuat yaitu sebesar 0,76. Pada saat terjadi hujan di area tangkapannya, air yang keluar dari mata air Goa Gremeng secara visual tampak berubah menjadi keruh. Namun pada saat hari tidak hujan, air yang keluar menjadi lebih jernih dibandingkan pada saat hujan.

Kondisi berbeda ditunjukkan oleh parameter TDS, nitrat, dan temperature air. Parameter ini menunjukkan korelasi yang negatif. Korelasi negatif yang sangat kuat ditunjukkan oleh parameter TDS yaitu sebesar $-0,85$. Sedangkan korelasi dengan level kuat ditunjukkan oleh parameter nitrat dan temperatur.

Ravbar (2007) menjelaskan bentuk korelasi positif dan negatif seperti ditunjukkan dari hasil pengukuran dilokasi penelitian adalah disebabkan oleh proses pelarutan (solution) dan pengenceran (dilution). Proses pelarutan memungkinkan terjadinya peningkatan konsentrasi parameter kualitas air akibat penambahan air hujan pada lorong vertical ataupun horizontal batuan karbonat. Sedangkan proses pengenceran terjadi karena penambahan jumlah air hujan mengakibatkan berkurangnya konsentrasi parameter kualitas air tersebut.

Berdasar waktu kejadiannya, nilai korelasi yang paling tinggi ditunjukkan pada hari yang sama antara kejadian hujan dengan saat pengukuran. Kondisi ini ditunjukkan oleh beberapa parameter kualitas air. Hasil ini menunjukkan adanya respon mata air yang cepat terhadap kejadian hujan di area tangkapannya. Sejalan dengan konsep waktu lintas, respon yang cepat mengindikasikan kondisi mata air yang sensitif dan rentan terhadap munculnya bahaya pencemaran di area tangkapannya (Ravbar, 2007; Andreo dkk, 2008; Goldscheider, 2002). Sejalan dengan pendapat tersebut, maka mata air karst Goa Gremeng diindikasikan memiliki sensitifitas yang tinggi.

Kondisi ini sejalan dengan temuan Widyastuti (2014) yang menyimpulkan bahwa sebagian besar wilayah karst Gunungsewu bagian timur memiliki tingkat kerentanan yang tinggi. 


\section{KESIMPULAN DAN SARAN}

\section{D.1. KESIMPULAN}

Berdasarkan hasil penelitian dapat ditarik beberapa kesimpulan yaitu :

1. Mata air karst Goa Gremeng memiliki tingkat sensitivitas yang tinggi terhadap hujan yang terjadi di area tangkapannya.

2. Parameter yang dapat digunakan sebagai indikator sensitivitas mata air Goa Gremeng adalah TDS, kekeruhan, nitrat dan temperatur.

\section{D.2. SARAN}

Berdasar pada kesimpulan yang dihasilkan dalam penelitian ini, dapat dirumuskan beberapa saran yang dapat digunakan dalam pengelolaan lingkungan pada area tangkapan mata air karst Goa Gremeng. Saran-sarang tersebut adalah sebagai berikut.

1. Mengingat sensitifitas mata air karst Goa Gremeng yang tinggi, maka sebaiknya perlu dicermati area-area yang digunakan sebagai lokasi pembuangan limbah baik limbah rumah tangga ataupun non rumah tangga.

2. Pemanfaatan pupuk pada lahan pertanian sebaiknya dilakukan tidak berlebihan.

\section{DAFTAR PUSTAKA}

Adji, T.N., 2010, Variasi spasialtemporal hidrogeokimia dan sifat aliran untuk karakterisasi system karst dinamis di sungai bawah tanah
Bribin, kabupaten Gunungkidul, DIY, Disertasi, Prodi Geografi, PPS Fakultas Geografi, UGM, Yogyakarta.

Andreo, B., Ravbar, R., Vias, J.M., 2008, Source vulnerability mapping in carbonate (karst) aquifers by extension of the COP method: application to pilot sites. Hydrogeology Journal. DOI 10.1007/s10040-008-0391-1.

Budiyanto, E., 2018, Penginderaan jauh dan system informasi geografis untuk penilaian kerentanan dan risiko pencemaran air tanah karst Gunungsewu di Kabupaten Gunungkidul, Disertasi, Fakultas Geografi, UGM, Yogyakarta.

Ford, D.C., dan William, P., 2007, Karst Hydrogeology and Geomorphology, John Willey \& Sons, Chicester.

Goldscheider, N., 2002, Hydogeology and vulnerability of karst system from the North Alps and the Swabian Alb. Dissertation, Universitat Karlsruhe, Karlsruhe.

Ravbar, N., 2007, The protection of karst waters : a comprehensive Slovene approach to vulnerability and contamination risk mapping. Zaloba ZRC Publishing. Karst Research Institute, Ljubljana.

Widyastuti, M., 2014. Kajian kerentanan air tanah terhadap pencemaran di daerah karst Gunungsewu, Studi di Daerah Aliran Sungai bawah tanah Bribin Kabupaten Gunungkidul dan Wonogiri, Disertasi, PPS, Fakultas Geografi, UGM, Yogyakarta. 